\title{
Hematological responses to hyperimmune plasma low dose administration in foals during weaning
}

\author{
Respostas hematológicas da administração de baixa dose de \\ plasma hiperimune em potros no período de desmame
}

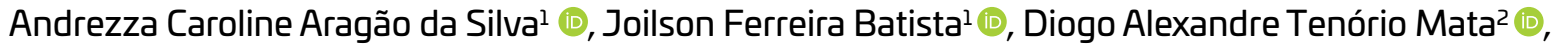
Karina Pessoa Oliveira ${ }^{3}$ (D), Tatiana Figueiredo Paiva ${ }^{2}$, Marcia Kikuyo Notomi ${ }^{3}$, Pierre Barnabé Escodro ${ }^{3^{*}}$ (1)
\end{abstract}

\begin{abstract}
Weaning is a development stage that brings maternal independence, change of management and feeding, leading to immune deficit. The objective of this study was to evaluate the hematological and biochemical parameters of foals in weaning phase after intravenous administration of hyperimmune plasma $(1 \mathrm{~mL} / \mathrm{Kg})$ in low dose. Ten foal weaned from the Mangalarga Machador breed were used, being divided in control (GC; $n=5$ ) and treated group (GT; n=5). The results obtained show that hematological and biochemical parameters of foals that received low doses of hyperimmune plasma were within the reference range for the equine species.
\end{abstract}

KEYWORDS: foal; Mangalarga Marchador; hemogram; serum biochemical

\begin{abstract}
RESUMO: O desmame é uma fase do desenvolvimento que traz independência materna, mudança de manejo e alimentação, levando ao déficit imunológico. O objetivo deste estudo foi avaliar os parâmetros hematológicos e bioquímicos de potros em fase de desmame após administraçáo intravenosa de plasma hiperimune $(1 \mathrm{~mL} / \mathrm{Kg})$ em baixa dose. Foram utilizados dez potros desmamados da raça Mangalarga Machador, sendo divididos em grupo controle (GC; $n=5)$ e grupo tratado $(\mathrm{GT} ; \mathrm{n}=5)$. Os resultados obtidos mostram que os parâmetros hematológicos e bioquímicos de potros que receberam baixas doses de plasma hiperimune estavam dentro da faixa de referência para a espécie equina.
\end{abstract}

PALAVRAS-CHAVE: potro; Mangalarga Marchador; hemograma; bioquímica sérica

\section{INTRODUCTION}

Equine plasma is a natural colloid composed of immunoglobulins (Ig): $\operatorname{IgG}$, IgA, $\operatorname{IgM}$, IgE, with a prevalence of $85 \%$ plasmatic IgG (MCLURE et al., 2001, WAGNER 2004, DAWSON et al.,2010). Hyperimmune plasma is obtained by plasmapheresis technique. The donor animal must be subjected previously to consecutive hyperimmunization vaccine protocols which increases plasma concentration of specific antibodies and multiple coagulation factors. (ESCODRO et al., 2013; NETO et al., 2018). Hyperimmune plasma is widely used in neonates and foals, being plasma valence correlated with dose, speed of administration, immunological competence, as well as management conditions and individual pathogenic virulence (DAWSON et al., 2010). It can be combined or supplemented to colostrum in situations of maternal and / or colostrum absence, colitis, immunodeficiency, failure to transfer passive immunity, septicemia and stress, such as weaning (ATHERTON; McKENZIE, 2011; ESCODRO et al., 2013). In natural conditions, weaning occurs before a new birth, ensuring greater maternal bond and foal's physiological and behavioral maintenance. However, this time was reduced by human management, occurring around the fourth month of age, when the stress caused by environmental changes, nutritional management and maternal disengagement, induces a suppression of the immune response mediated by cells due to increase in cortisol and catecholamines, generating greater susceptibility to illnesses and weight loss (SPINDOLA et al., 2017; LANSADE et al., 2018; WULF et al., 2018). 
For decades, the usual dosage of plasma has been 10 to 20 $\mathrm{mL} / \mathrm{kg}$ intravenously in a single dose, recommended due to standard immunoglobulins inefficiency ( $\mathrm{IgG}>800 \mathrm{mg} / \mathrm{dL}$ ). Hyperimmune plasma bags usually contain IgG concentrations between 1500 and $2500 \mathrm{mg} / \mathrm{dL}$ (FRECCERO et al., 2017). However, the minimum dose of immune stimulation in these animals is not determined, as in human medicine. Therefore, the aim of this study was to evaluate hematological and biochemical parameters of foals in the weaning phase after hyperimmune plasma low dose administration.

\section{MATERIAL AND METHODS}

This study was approved by Animal Ethics and Experimentation Committee - CEUA, of Alagoas Federal University (Protocol No. 14/2014). The experiment was carried out in a farm, located in Cajueiro, State of Alagoas, between June and July 2017, lasting 42 days. Ten Mangalarga Machador foals were used, originated from embryo transfer, of both sexes, aged six months, in the process of weaning, weighing $120 \pm 40 \mathrm{~kg}$. Foals were divided into two groups with five animals each: control group (CG), submitted to the administration of $1 \mathrm{~mL} / \mathrm{kg} /$ IV of $0.9 \%$ sodium chloride and treated group (GT), which received $1 \mathrm{~mL} / \mathrm{kg} / \mathrm{IV}$ of hyperimmune plasma obtained by automated plasmapheresis as described by Escodro et al. (2013). The foals were grouped in two or three in collective pens, with water, food (Cynodon spp.) and mineral ad libitum access, with daily notes on the animals. In the morning (time 0 ), blood samples were collected from all animals by jugular vein venipuncture using $5 \mathrm{~mL}$ tubes containing EDTA anticoagulant, $5 \mathrm{~mL}$ containing fluoride / EDTA and $10 \mathrm{~mL}$ without anticoagulant using Vacutainer ${ }^{\circledR}$ system. Was also performed foals physical examination: heart rate, respiratory rate, capillary filling time and rectal temperature, and weighing the animals using a weight tape for horses. Intravenous administration of $0.9 \%$ sodium chloride (GC) or hyperimmune plasma (GT), at a dose of $1 \mathrm{~mL} / \mathrm{kg}$, was performed through the left jugular vein of each animal. After the administration of plasma or sodium chloride $0.9 \%$ in foals, new samples were taken after $12,24,48,72$ and 96 hours and in the $7^{\text {th }}$, $14^{\text {th }}, 28^{\text {th }}$ and $35^{\text {th }}$ day. Hematological and blood biochemistry parameters of all animals were evaluated. Hematological evaluation included total red blood cell, leukocyte and platelet counts; determination of globular volume (VG) and hemoglobin concentration in automated equipment (BC $2800 \mathrm{Vet}$, Mindray) with subsequent calculation of the mean corpuscular volume (VCM) and mean corpuscular hemoglobin (CHCM) values. Cells morphological evaluation and differential count was performed by blood smear stained with Panoptic Rapid ${ }^{\circledR}$. For blood biochemistry evaluation, the tubes with fluoride / EDTA and without EDTA were centrifuged for 10 minutes at $3000 \mathrm{rpm}$ with subsequent separation of plasma and serum, respectively. Plasma glucose (K082-2) and serum creatinine (K067-1), urea (K056-1), total protein (K031-1) and albumin
(K040-1) measurements were performed using commercial kits (Bioclin ${ }^{\circledR}$, Quibasa, MG, Brazil) according to the manufacturer's instructions. Samples were analyzed in semi-automated equipment Spectrum ${ }^{\circledast}$ (Celer). Fibrinogen measurement was performed using the heat precipitation technique. Globulin value was obtained by subtracting the values of total proteins and albumin (globulins = total proteins - albumin). All procedures were performed at the Veterinary Clinical Pathology Laboratory of Federal University of Alagoas. In order to verify possible difference between groups and normal distribution, data were first submitted to the Shapiro-Wilk test. Treatments variance analysis was defined with significance of $\mathrm{P}<0.05$ and Student's $\mathrm{t}$ test was used to verify possible difference between groups. Variance analysis was performed, followed by the Tukey test. All analyzes were performed using the GraphPad Prism program, Version 5.0 (Trial) 2007 and assuming a probability of error of $5 \%$.

\section{RESULTS AND DISCUSSION}

Along the 42 days experiment, foals were characterized as healthy, without any clinical sign of illness. On weaning day, the initial weight of these animals was $120 \pm 40 \mathrm{~kg}$, with body maintenance being observed in both groups evaluated until 72 hours, even after the administration of hyperimmune plasma in treated group (Fig. 1). Unlike what was described by Wulf et al. (2018), who pointed out reduction of weight on the first day of weaning with negative body maintenance until the 6th day, reporting greater wear in females in this period, but without significant difference between genders. Throughout days of evaluation, animals in control group as well as in treated group achieved significant weight gain from the seventh day of evaluation, showing that administration of plasma appears to have no influence on weight gain of animals in the administered dose (Fig. 1).

In dogs, oral administration of hyperimmune plasma $(1.5 \mathrm{~mL} / 100 \mathrm{~g}$ of body weight) promoted weight gain in the first eight hours of life (Mila et al., 2016). In pigs, the use of dehydrated plasma (2.5\%) is already a reality, being added during the weaning phase, promoting the stimulation of appetite for 15 to 28 days after weaning (BUTOLO et al., 1999), resulting in increased weight gain and growth rate of these animals (KRUMRYCH et al., 2013). Heart rate and respiratory rate over the evaluation days in both groups significantly decreased, as shown in Fig. 2.

The increase in heart and respiratory rate was expected until the foals adapted to handling and handlers. Elevation of these two parameters observed in the first evaluation period was probably due to interactions between physiological systems and the immune response linked to stress in domestic animals (STALEY et al., 2018). Total protein and fibrinogen concentration when correlated allowed the identification of significant reduction in fibrinogen concentration in the treated group $(0.04 \pm 0.08 \mathrm{~g} / \mathrm{dL})$ at $12^{\text {nd }}$ hour (Fig. 3), corroborating 

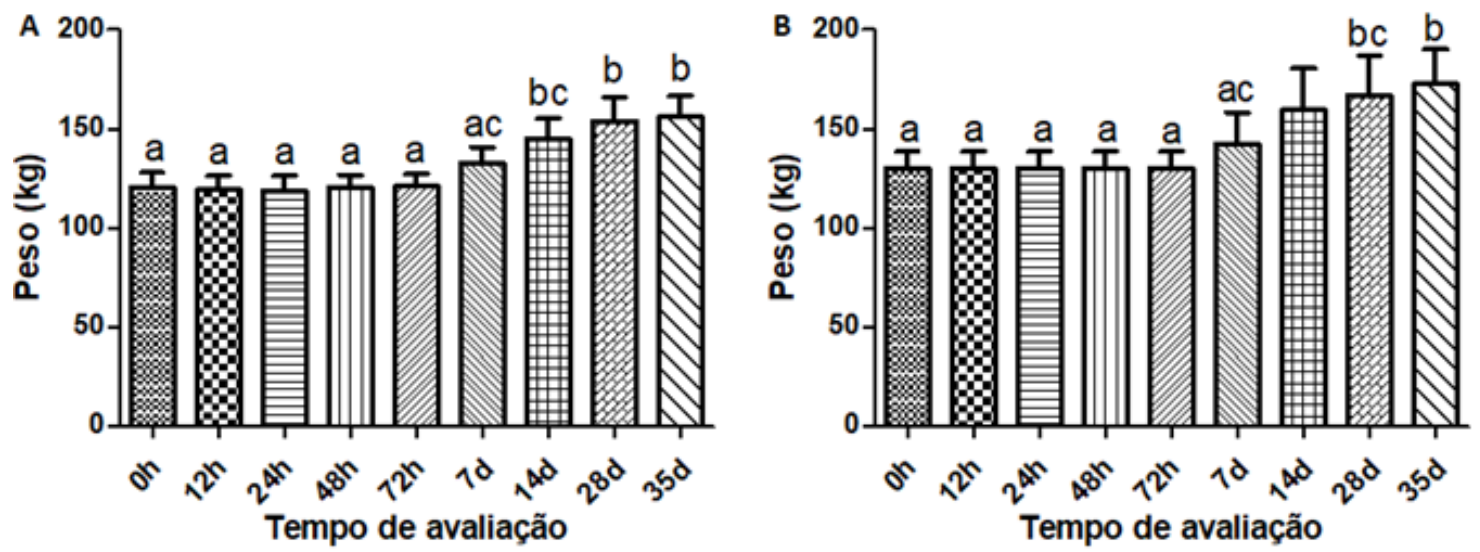

Figure 1. Graphical representation of foals weight gain (Kg) that received l mL / Kg of 0.9\% sodium chloride (control group - GC; $n=5$ ) or hyperimmune plasma (treated group - GT; $n=5$ ) intravenously, before administration (Oh), 12, 24, 48 and 72 hours and 7, 14 , 28 and 35 days after administration. Means followed by the same letters do not differ by Tukey's test $(P>0.05)$.
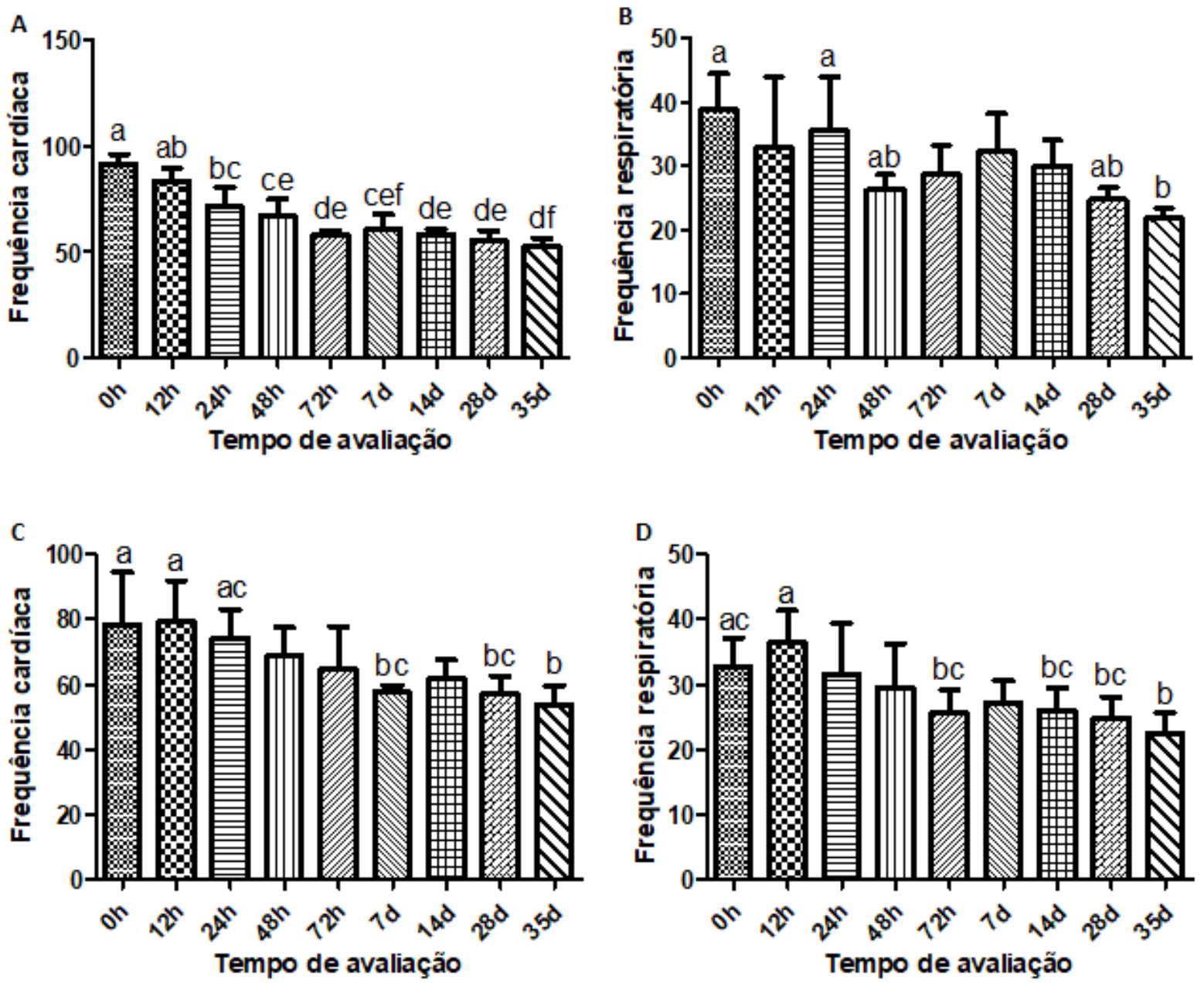

Figure 2. Graphical representation of heart rate (bpm) and respiratory rate (mpm) of foals that received l $\mathrm{mL} / \mathrm{kg}$ of $0.9 \% \mathrm{sodium}$ chloride (control group - CC; $n=5$ ) ( $A$ and C) and hyperimmune plasma (treated group - GT; $n=5$ ) (B and D) intravenously, before administration (Oh), 12, 24, 48 and 72 hours and 7, 14, 28 and 35 days after administration. Means followed by the same letters do not differ by Tukey's test $(P>0.05)$. 
A

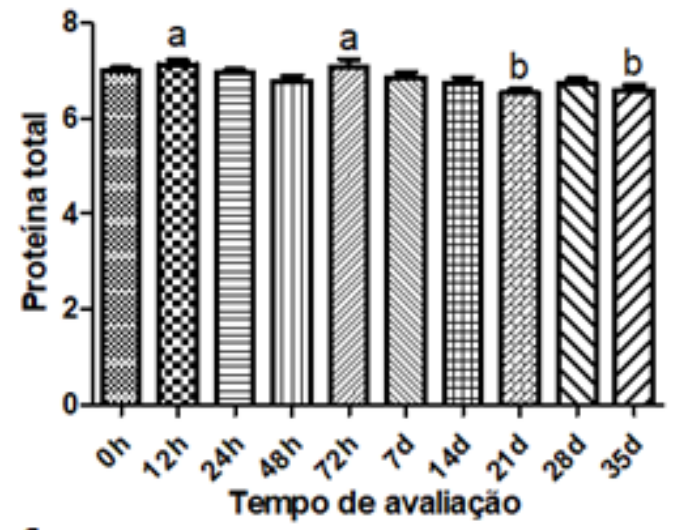

C

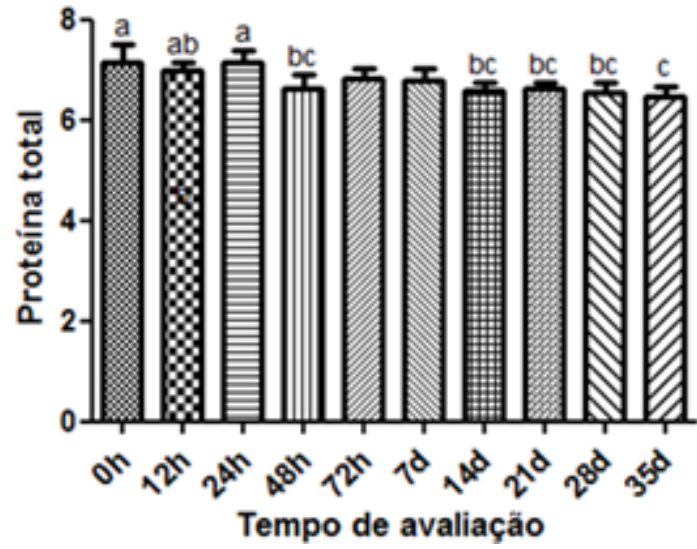

B

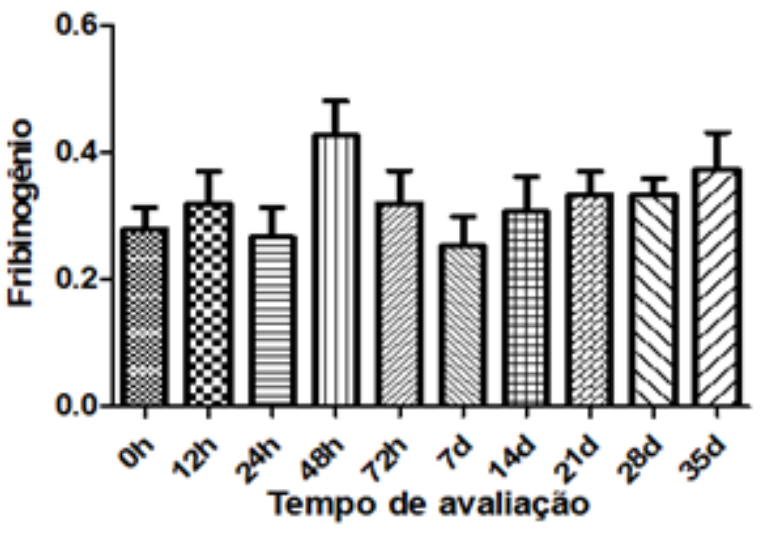

D

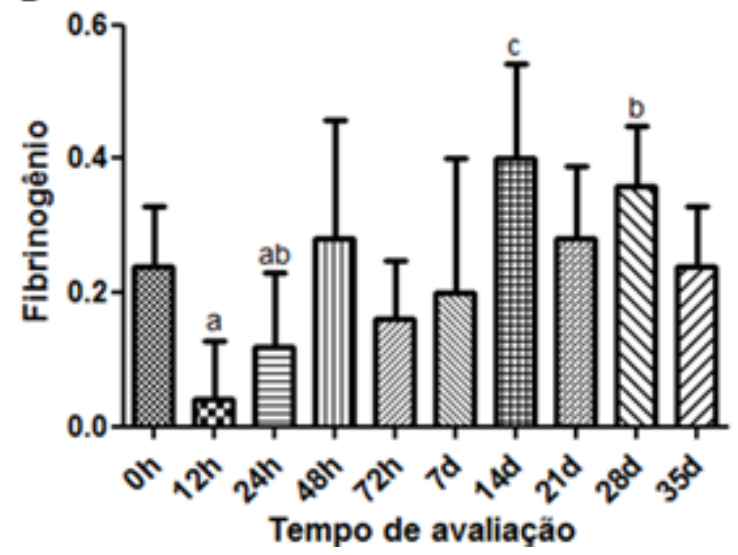

Figure 3. Graphical representation of total protein $(\mathrm{g} / \mathrm{dL}$ ) and fibrinogen concentration $(\mathrm{g} / \mathrm{dL}$ ) of foals that received $\mathrm{l} \mathrm{mL} / \mathrm{kg}$ of $0.9 \%$ sodium chloride (control group - GC; $n=5$ ) ( $A$ and $B$ ) and hyperimmune plasma (treated group - $G T ; n=5)(B$ and $C$ ) intravenously, before administration (Oh), 12, 24, 48 and 72 hours and 7, 14, 28 and 35 days after administration. Means followed by the same letters do not differ by Tukey's test $(P>0.05)$.

Hollis et al. (2016) who observed that addition of hyperimmune plasma provides an expansion of plasma volume, resulting in fibrinogen dilution in foals bloodstream.

The stress caused by handling animals for first blood collection may have contributed to elevate glucose values, as observed in the treated group before the administration of hyperimmune plasma $(114.2 \pm 19.4 \mathrm{mg} / \mathrm{dL})$ (Table 1), as well as a result of action of catecholamines, releasing glucose into circulation. This, points out that animals that are not conditioned to activities and management and are submitted to a large stress, due to lack of well-being, presents a negative energetic oscillation by catabolism of proteins losing their potential energy (DURHAM, 2006; RAMALHO et al., 2012).

Regarding the erythrogram, no significant differences were found between total red blood cell count, hemoglobin concentration, globular volume value (VG), mean corpuscular volume (CMV), mean corpuscular hemoglobin concentration (CHCM) in any of the treatments and times evaluated, indicating that using hyperimmune plasma did not negatively influence foals' erythrogram. On the other hand, there was a significant reduction in platelet count between groups at the initial moment (CG: 199.5 \pm 33.4 x 103 / $\mu \mathrm{L}$; GT: $160.4 \pm$
Table 1. Mean values and standard deviations of the plasma glucose concentration of foals that received $1 \mathrm{~mL} / \mathrm{Kg}$ of $0.9 \%$ sodium chloride (control group - GC; $n=5$ ) and hyperimmune plasma (treated group - GT; $n=5$ ) intravenously, before administration (Oh) and 12 hours after administration.

\begin{tabular}{l|c|c|c|c}
\multirow{2}{*}{ Análises } & \multicolumn{4}{|c}{ Tempo } \\
\cline { 2 - 5 } & \multicolumn{3}{|c|}{ Oh } & \multicolumn{2}{c}{$12 \mathrm{~h}$} \\
\cline { 2 - 5 } & GC & GT & GC & GT \\
\hline \multirow{3}{*}{ Glicose (mg/dL) } & $94,5 \pm$ & $114,2 \pm$ & $98,3 \pm$ & $110,8 \pm$ \\
& $10,8^{\mathrm{a}}$ & $19,4^{\mathrm{b}}$ & $10,8^{\mathrm{a}}$ & $11,5^{\mathrm{b}}$ \\
\hline
\end{tabular}

Different lower case letters on the same line differ from each other in each evaluation period (Mann - Witney test and t test, $\mathrm{P}<0.05$ )

$26.5 \times 103 / \mu \mathrm{L})$ and at $24^{\text {th }}$ hour (CG: $175.9 \pm 55.5 \times 103 /$ $\mu \mathrm{L}$; GT: $156.6 \pm 22.0 \times 103 / \mu \mathrm{L})$ after intravenous administration. However, it was observed, after administration of the hyperimmune plasma, a significant increase in leukocytes number $(14.96 \pm 5.15 \times 103 / \mu \mathrm{L})$ in treated group, in contrast to control group $(12.67 \pm 2.66 \times 103 / \mu \mathrm{L})$, highlighting the occurrence of body's immune response, since erythrocyte and leukocyte concentration of plasma bags are 
Table 2. Mean values and standard deviations of foals leukogram that received $1 \mathrm{~mL} / \mathrm{kg}$ of $0.9 \%$ sodium chloride (control group - GC; $n=5$ ) and hyperimmune plasma (treated group - GT; $n=5$ ) intravenously, before administration (Oh), $12,24,48$ and 72 hours and 7 , 14,28 and 35 days after administration.

\begin{tabular}{|c|c|c|c|c|c|c|c|c|c|c|}
\hline \multirow{3}{*}{ Analysis } & \multicolumn{10}{|c|}{ Time } \\
\hline & \multicolumn{2}{|c|}{ Oh } & \multicolumn{2}{|c|}{$12 \mathrm{~h}$} & \multicolumn{2}{|c|}{$24 \mathrm{~h}$} & \multicolumn{2}{|c|}{$48 h$} & \multicolumn{2}{|c|}{$72 \mathrm{~h}$} \\
\hline & GC & GT & GC & CT & GC & GT & GC & GT & GC & GT \\
\hline Leu (x10/uL) & $\begin{array}{c}12.38 \pm \\
2.19\end{array}$ & $\begin{array}{c}18,68 \pm \\
2,60^{\circ}\end{array}$ & $\begin{array}{c}13,37 \pm \\
2,82\end{array}$ & $\begin{array}{c}12,70 \pm \\
2,88\end{array}$ & $\begin{array}{c}12,67 \pm \\
2,66\end{array}$ & $\begin{array}{c}14,96 \pm \\
5,15\end{array}$ & $\begin{array}{c}11,70 \pm \\
2,87\end{array}$ & $\begin{array}{c}13,47 \pm \\
3,41\end{array}$ & $\begin{array}{c}12,45 \pm \\
3,52\end{array}$ & $\begin{array}{c}11,22 \pm \\
2,40\end{array}$ \\
\hline Lymph(x10³/uL) & $\begin{array}{c}6.55 \pm \\
1.38^{\mathrm{a}}\end{array}$ & $\begin{array}{c}11,11 \pm \\
2,10^{\mathrm{b}}\end{array}$ & $\begin{array}{c}5,87 \pm \\
1,74\end{array}$ & $\begin{array}{c}7,36 \pm \\
1,30\end{array}$ & $\begin{array}{c}4,78 \pm \\
2,31^{a}\end{array}$ & $\begin{array}{l}8,61 \pm \\
3,22^{\mathrm{b}}\end{array}$ & $\begin{array}{c}5,57 \pm \\
1,66^{a}\end{array}$ & $\begin{array}{c}7,82 \pm \\
2,02^{\mathrm{b}}\end{array}$ & $\begin{array}{c}5,86 \pm \\
1,94\end{array}$ & $\begin{array}{c}7,06 \pm \\
1,13\end{array}$ \\
\hline Mono (x10/uL) & $\begin{array}{c}0.83 \pm \\
0.22^{a}\end{array}$ & $\begin{array}{c}0,48 \pm \\
0,19^{\circ}\end{array}$ & $\begin{array}{c}0,90 \pm \\
0,33^{a}\end{array}$ & $\begin{array}{c}0,36 \pm \\
0,23^{b}\end{array}$ & $\begin{array}{c}0,75 \pm \\
0,31\end{array}$ & $\begin{array}{c}0,52 \pm \\
0,28\end{array}$ & $\begin{array}{c}0,74 \pm \\
0,28^{a}\end{array}$ & $\begin{array}{c}0,34 \pm \\
0,26^{b}\end{array}$ & $\begin{array}{c}0,75 \pm \\
0,24^{a}\end{array}$ & $\begin{array}{c}0,28 \pm \\
0,34^{b}\end{array}$ \\
\hline Gran (x10³/uL) & $\begin{array}{c}4,49 \pm \\
1,799^{a}\end{array}$ & $\begin{array}{c}7,09 \pm \\
1,72^{\circ}\end{array}$ & $\begin{array}{c}6,67 \pm \\
1,91\end{array}$ & $\begin{array}{c}4,98 \pm \\
1,64\end{array}$ & $\begin{array}{c}6,94 \pm \\
3,43\end{array}$ & $\begin{array}{c}5,83 \pm \\
1,93\end{array}$ & $\begin{array}{c}5,41 \pm \\
2,04\end{array}$ & $\begin{array}{c}5,31 \pm \\
1,47\end{array}$ & $\begin{array}{c}5,87 \pm \\
2,12\end{array}$ & $\begin{array}{c}3,88 \pm \\
1,09\end{array}$ \\
\hline Neu. Seg. (x10³/uL) & $\begin{array}{c}3,20 \pm \\
1,25\end{array}$ & $\begin{array}{c}4,22 \pm \\
1,03\end{array}$ & $\begin{array}{c}3,81 \pm \\
1,49\end{array}$ & $\begin{array}{c}2,71 \pm \\
0,52\end{array}$ & $\begin{array}{c}4,10 \pm \\
2,39\end{array}$ & $\begin{array}{c}3,68 \pm \\
1,20\end{array}$ & $\begin{array}{c}3,63 \pm \\
1,68\end{array}$ & $\begin{array}{c}3,72 \pm \\
0,80\end{array}$ & $\begin{array}{c}3,94 \pm \\
2,04\end{array}$ & $\begin{array}{c}3,37 \pm \\
1,00\end{array}$ \\
\hline Neu. Bast. (x10³/uL) & $\begin{array}{c}0,58 \pm \\
0,58\end{array}$ & $\begin{array}{c}0,52 \pm \\
0,32\end{array}$ & $\begin{array}{c}0,68 \pm \\
0,83\end{array}$ & $\begin{array}{c}0,41 \pm \\
0,27\end{array}$ & $\begin{array}{c}0,40 \pm \\
0,52\end{array}$ & $\begin{array}{c}0,29 \pm \\
0,22\end{array}$ & $\begin{array}{c}0,34 \pm \\
0,35\end{array}$ & $\begin{array}{c}0,70 \pm \\
0,19\end{array}$ & $\begin{array}{c}0,19 \pm \\
0,17^{a}\end{array}$ & $\begin{array}{c}0,51 \pm \\
0,16^{b}\end{array}$ \\
\hline Eosinophils (x10³/uL) & $\begin{array}{c}0,35 \pm \\
0,31\end{array}$ & $\begin{array}{c}0,36 \pm \\
0,32\end{array}$ & $\begin{array}{c}0,23 \pm \\
0,32\end{array}$ & $\begin{array}{c}0,35 \pm \\
0,32\end{array}$ & $\begin{array}{c}0,22 \pm \\
0,32^{a}\end{array}$ & $\begin{array}{c}0,57 \pm \\
0,33^{\mathrm{b}}\end{array}$ & $\begin{array}{c}0,25 \pm \\
0,33\end{array}$ & $\begin{array}{c}0,40 \pm \\
0,34\end{array}$ & $\begin{array}{c}0,37 \pm \\
0,34\end{array}$ & $\begin{array}{c}0,44 \pm \\
0,35\end{array}$ \\
\hline \multirow[t]{3}{*}{ Basophils(x10³/uL) } & $\begin{array}{c}0,00 \pm \\
0,00\end{array}$ & $\begin{array}{c}0,00 \pm \\
0,00\end{array}$ & $\begin{array}{c}0,01 \pm \\
0,05\end{array}$ & $\begin{array}{c}0,02 \pm \\
0,04\end{array}$ & $\begin{array}{c}0,00 \pm \\
0,00\end{array}$ & $\begin{array}{c}0,00 \pm \\
0,00\end{array}$ & $\begin{array}{c}0,00 \pm \\
0,00\end{array}$ & $\begin{array}{c}0,05 \pm \\
0,09\end{array}$ & $\begin{array}{c}0,01 \pm \\
0,03\end{array}$ & $\begin{array}{c}0,00 \pm \\
0,00\end{array}$ \\
\hline & \multicolumn{2}{|c|}{$7 d$} & \multicolumn{2}{|c|}{$14 d$} & \multicolumn{2}{|c|}{$21 d$} & \multicolumn{2}{|c|}{$28 d$} & \multicolumn{2}{|c|}{$35 d$} \\
\hline & GC & GT & GC & CT & GC & GT & GC & GT & GC & GT \\
\hline Leu (x10³/uL) & $\begin{array}{c}12,93 \pm \\
3,55\end{array}$ & $\begin{array}{c}12,32 \pm \\
4,09\end{array}$ & $\begin{array}{c}13,62 \pm \\
2,62\end{array}$ & $\begin{array}{c}16,38 \pm \\
2,97\end{array}$ & $\begin{array}{c}13,42 \pm \\
3,85\end{array}$ & $\begin{array}{c}14,17 \pm \\
2,20\end{array}$ & $\begin{array}{c}12,87 \pm \\
3,02\end{array}$ & $\begin{array}{c}13,62 \pm \\
2,14\end{array}$ & $\begin{array}{c}11,37 \pm \\
2,24\end{array}$ & $\begin{array}{c}12,62 \pm \\
2,51\end{array}$ \\
\hline Lymph (x10³/uL) & $\begin{array}{c}5,87 \pm \\
2,20\end{array}$ & $\begin{array}{c}6,55 \pm \\
1,25\end{array}$ & $\begin{array}{c}7,81 \pm \\
1,56\end{array}$ & $\begin{array}{c}9,40 \pm \\
2,77\end{array}$ & $\begin{array}{c}7,87 \pm \\
1,95\end{array}$ & $\begin{array}{c}7,66 \pm \\
1,57\end{array}$ & $\begin{array}{c}7,39 \pm \\
1,83\end{array}$ & $\begin{array}{c}8,24 \pm \\
1,17\end{array}$ & $\begin{array}{c}6,34 \pm \\
1,41\end{array}$ & $\begin{array}{c}7,04 \pm \\
1,30\end{array}$ \\
\hline Mono (x103/uL) & $\begin{array}{c}0,87 \pm \\
0,40^{a}\end{array}$ & $\begin{array}{c}0,26 \pm \\
0,18^{\mathrm{b}}\end{array}$ & $\begin{array}{c}0,74 \pm \\
0,20\end{array}$ & $\begin{array}{c}0,54 \pm \\
0,23\end{array}$ & $\begin{array}{c}0,71 \pm \\
0,30\end{array}$ & $\begin{array}{c}0,60 \pm \\
0,16\end{array}$ & $\begin{array}{c}0,72 \pm \\
0,22\end{array}$ & $\begin{array}{c}0,70 \pm \\
0,14\end{array}$ & $\begin{array}{c}0,69 \pm \\
0,22^{a}\end{array}$ & $\begin{array}{c}0,26 \pm \\
0,27^{b}\end{array}$ \\
\hline Gran (x10³/uL) & $\begin{array}{c}6,17 \pm \\
3,31\end{array}$ & $\begin{array}{c}5,51 \pm \\
3,14\end{array}$ & $\begin{array}{c}5,15 \pm \\
1,29\end{array}$ & $\begin{array}{c}6,44 \pm \\
0,90\end{array}$ & $\begin{array}{c}4,82 \pm \\
2,94\end{array}$ & $\begin{array}{c}5,91 \pm \\
0,61\end{array}$ & $\begin{array}{c}4,77 \pm \\
1,35\end{array}$ & $\begin{array}{c}5,18 \pm \\
0,42\end{array}$ & $\begin{array}{c}4,35 \pm \\
0,97\end{array}$ & $\begin{array}{c}5,32 \pm \\
1,45\end{array}$ \\
\hline Neu. Seg. (x10³/uL) & $\begin{array}{c}4,54 \pm \\
2,02\end{array}$ & $\begin{array}{c}3,32 \pm \\
1,27\end{array}$ & $\begin{array}{c}3,84 \pm \\
1,40\end{array}$ & $\begin{array}{c}3,64 \pm \\
0,64\end{array}$ & $\begin{array}{c}3,23 \pm \\
0,95\end{array}$ & $\begin{array}{c}3,67 \pm \\
0,81\end{array}$ & $\begin{array}{c}3,48 \pm \\
1,57\end{array}$ & $\begin{array}{c}4,05 \pm \\
1,79\end{array}$ & $\begin{array}{c}3,25 \pm \\
1,19\end{array}$ & $\begin{array}{c}2,96 \pm \\
0,66\end{array}$ \\
\hline Neu. Bast. (x10³/uL) & $\begin{array}{c}0,17 \pm \\
0,20\end{array}$ & $\begin{array}{c}0,37 \pm \\
0,30\end{array}$ & $\begin{array}{c}0,45 \pm \\
0,47\end{array}$ & $\begin{array}{c}0,12 \pm \\
0,20\end{array}$ & $\begin{array}{c}0,29 \pm \\
0,24\end{array}$ & $\begin{array}{c}0,20 \pm \\
0,14\end{array}$ & $\begin{array}{c}0,22 \pm \\
0,28\end{array}$ & $\begin{array}{c}0,37 \pm \\
0,24\end{array}$ & $\begin{array}{c}0,21 \pm \\
0,20\end{array}$ & $\begin{array}{c}0,16 \pm \\
0,12\end{array}$ \\
\hline Eosinophils (xl0³/uL) & $\begin{array}{c}0,34 \pm \\
0,35\end{array}$ & $\begin{array}{c}0,51 \pm \\
0,36\end{array}$ & $\begin{array}{c}0,41 \pm \\
0,37\end{array}$ & $\begin{array}{c}0,27 \pm \\
0,38\end{array}$ & $\begin{array}{c}0,50 \pm \\
0,39\end{array}$ & $\begin{array}{c}0,47 \pm \\
0,32\end{array}$ & $\begin{array}{c}0,47 \pm \\
0,32\end{array}$ & $\begin{array}{c}0,86 \pm \\
0,29\end{array}$ & $\begin{array}{c}0,44 \pm \\
0,24\end{array}$ & $\begin{array}{c}0,30 \pm \\
0,17\end{array}$ \\
\hline Basophils (x10/uL) & $\begin{array}{c}0,03 \pm \\
0,10\end{array}$ & $\begin{array}{c}0,00 \pm \\
0,00\end{array}$ & $\begin{array}{c}0,01 \pm \\
0,04\end{array}$ & $\begin{array}{c}0,00 \pm \\
0,00\end{array}$ & $\begin{array}{c}0,00 \pm \\
0,00\end{array}$ & $\begin{array}{c}0,00 \pm \\
0,00\end{array}$ & $\begin{array}{c}0,00 \pm \\
0,00\end{array}$ & $\begin{array}{c}0,00 \pm \\
0,00\end{array}$ & $\begin{array}{c}0,00 \pm \\
0,00\end{array}$ & $\begin{array}{c}0,00 \pm \\
0,00\end{array}$ \\
\hline
\end{tabular}

Different letters on the same line differ from each other in each evaluation period (Mann - Witney test and t test, $\mathrm{P}<0.05$ ).

Leu: leukocytes, Lymph: lymphocytes, Mono: monocytes, Neu. Mon .: segmented neutrophils, Neu. Bast .: bastonet neutrophils. Reference limits for horses according to WEISS \& WARDROP (2010).

low (FRECCERO et al., 2017), with subsequent decrease during the experiment (Tab. 2). An increase in lymphocyte count was also observed in treated group when compared to control group, with an increase in lymphocytes between $24^{\text {th }}$ and $48^{\text {th }}$ hour (GT: $8.61 \pm 3.22 \times 103 / \mu \mathrm{L}$ and $7.82 \pm 2.02$; CG: $4.78 \pm 2.31 \times 103 / \mu \mathrm{L}$ and $5.57 \pm 1.66$, respectively), with a higher count of the number of lymphocytes on $14^{\text {th }}$ day (GT: $9.40 \pm 2.77 \times 103 / \mu \mathrm{L})$ ), when compared to the evaluation at 24 hours after treatment (GT: $8.61 \pm 3.22 \mathrm{x}$ $103 / \mu \mathrm{L}$ ), indicating the release of mature cells into bloodstream (ATHERTON; McKENZIE, 2011; KRUMRYCH et al., 2013). Absence of eosinophilia indicates lack of hypersensitivity stimuli or any reaction to the administration of hyperimmune plasma in animals. In foals, the potential of 
immune cells, such as neutrophils and macrophages, to control primary infections, when compared to adults, is lower, since the phagocytic capacity of neutrophils in foals is limited until the age of three to four weeks, noting that phagocytic opsonic activity of foals' neutrophils improves when mixed with adult serum or plasma (GRONDAHL et al., 1999; DAWSON et al., 2010). Monocyte count showed a significant reduction at $12^{\text {nd }}, 48^{\text {th }}$ and $72^{\text {nd }}$ hour until 35 days of study in treated group. On the other hand, the neutrophil count showed a significant increase at $72^{\text {nd }}$ hour. No significant changes were observed in basophils and segmented neutrophils count (Table 2). Assessing gradual and abrupt weaning in foals, Tunner et al. (2003) showed that total white blood cells $(\mathrm{P}<0.01)$ and total neutrophil count $(\mathrm{P}<0.05)$ increased substantially in foals submitted to abrupt weaning.
Serum biochemistry is useful to identify high-risk foals. In the present study, renal metabolites (creatinine and urea) remained within the reference limits and without differences between groups, demonstrating that there was no oscillation of these metabolites in foals treated with hyperimmune plasma. Data referring to albumin concentration (GC: $4.25 \pm 0.29 \mathrm{mg}$ / dL; GT: $3.40 \pm 1.03 \mathrm{mg} / \mathrm{dL}$ ) and globulin concentration (GC: $2.37 \pm 0.31 \mathrm{mg} / \mathrm{dL}$; GT: $3.43 \pm 0.91 \mathrm{mg} / \mathrm{dL}$ ) there were no significant differences between evaluated groups evaluated, as well as demonstrated by HOWARD et al. (2008).

\section{CONCLUSION}

Hematological and biochemical parameters of foals in the weaning phase that received a low dose of hyperimmune plasma were within the normal range considering equine species.

\section{REFERENCES}

ATHERTON, R.P.; MCKENZIE, H.C. Efficacy of Hyperimmunized Plasma in the Treatment of Horses with Acute Colitis. Journal of Equine Veterinary Science, v.31, p.19-25, 2011.

BUTOLO, E. F. et al. Uso de plasma suíno desidratado por spraydryer na dieta de leitões desmamados precocemente. Revista Brasileira de Zootecnia, v. 28, n. 2, p. 326-333, 1999.

DAWSON, T.R.M.Y.; HOROHOV, D.W.; MEIJER, W.G.; MUSCATELLO, G. Current understanding of the equine immune response to Rhodococcus equi. An immunological review of $R$. equi pneumonia. Veterinary Immunology and Immunopathology, v.l35, p.l-11, 2010.

DURHAM, A. E. Clinical application of parenteral nutrition in the treatment of five ponies and one donkey with hyperlipaemia. Veterinary Record, v. 158, p. 159-164, 2006.

ESCODRO, P.B.; BERNADO, J.O.; ROVERI, E.G.; ESCODRO, L.O.; OLIVEIRA, C.F.; FONSECA, L.FS.; LOPES, C.R.A.; TONHOLO, J.; NASCIMENTO, T.G. Padronização da técnica de plasmaférese automatizada em equinos. Arquivo Brasileiro de Medicina Veterinária e Zootecnia, v.65, n.4, p.1049-1056, 2013.

FRECCERO, F.; MARIELLA, J.; LANCI, A.; COTIGNOLI, C.; CASTAGNETTI, C. Efficacy and Safety of a Commercial FreshFrozen Hyperimmune Plasma in Foals With Failure of Passive Transfer of Immunity. Journal of Equine Veterinary Science, v.48, p.174-181, 2017. DOI: 10.1016/j.jevs.2016.08.019.

GRONDAHL, G.; JOHANISSON, A.; DEMMERS, S.; JENSENWAERN, M. Influence of age and plasma treatment on neutrophil phagocytosis and CD18 expression in foals. Veterinary Microbiology, v.65, p.24l-254, 1999.

HOLLIS, A.R.; WILKINS, P.A.; TENNENT-BROWN, B.; PALMER, J.E.; BOSTON, R.C. The effect of intravenous fresh frozen plasma administration on fibrinogen and albumin concentrations in sick neonatal foals. Equine Veterinary Education, v.28, p.145-149, 2016.

HOWARD, D. L.; FERNANDES, W. R.; SOUZA, A. T.; LEAL, M. L. R.; MIRANDOLA, R. M. S.; BENSI, F. J. Total protein, albumin and globulin of healthy developing brazilian sport horse (brasileiro de hipismo) fillies. Ars Veterinaria, v.24, n.2, 077-082, 2008.
KRUMRYCH, W.; ZBYLUT, J.; GOŁYŃSKI, M.; MARKIEWICZ, H. Oxidant/bioprodutos status assessment of blood in selected equine diseases. Bulletin of the Veterinary Institute in Pulawy, v.57, p.225-230, 2013.

LANSADE, L.; FOURY, A.; REIGNER, F.; VIDAMENT, M.; GUETTIER, E.; BOUVET, G.; SOULET, D.; PARIAS, C.; RUET, A.; MACH, N.; LÉVY, F.; MOISAN, M.P. Progressive habituation to separation alleviates the negative effects of weaning in the mother and foal. Psychoneuroendocrinology, v.97, 11, p.59-68, 2018.

LYCH, E.M.; EARLEY, B.; MCGEE, M.; DOYLE, S. Effect of abrupt weaning at housing on leukocyte distribution, functional activity of neutrophils, and acute phase protein response of beef calves. BMC Veterinary Research, v.6, n.39, p. 1-9, 2010.

MCLURE, J.T.; DELUCA, J.L; LUNN, D.P.; MILLER, J. Evaluation of IG concentration and I Gubisotypes in foals with complete or partial failure of passive transfer after administration of intravenous serum or plasma. Equine Veterinary Journal, v.7, ก.33, p.681-686, 2001.

MILA, H.; GRELLET, A.; MARIANI, C.; FEUGIER, A.; GUARD, B.; SCHODOLSKI, J.; STEINER, J.; CHASTANT-MAILLARD, S. Natural and artificial hyperimmune solutions: Impact on health in puppies. Reproducrion in Domestic Animals, v.5l, n.3, p.l-7, 2016.

NETO, C.A.V.C.; OLIVEIRA-FILHO, J.P.; DELFIOL, D.J.Z.; BADIAL, P.R.; ARAÚJO JÚNIOR, J.P.; CRUZ, T.F.; TENÓRIO, M.S. \& BORGES, A. S. Proteinogram and serum IgG concentration in newborn foals up to thirty days of life treated with plasma. Pesquisa Veterinária Brasileira, v.38, n.5, p.795-805, 2018.

PALO, P.D.; MAGGIOLINO,A.;ALBENZIO, M.; CASALINO, E.; NEGLIA, G.; CENTODUCATI, G.; TATEO, A. technique Survey of biochemical and oxidative profile in donkey foals suckled with one natural and one semi-artificial. Plos One, 2018.

RAMALHO, L.O.; CAIADO, J.C.C.; SOUZA, V.R.C.; COELHO, C.S. Glycemy and serum concetrations of insulin, triglycerides and cortisol in Quarter horses and crossbred submitted to team ropping. Brazilian Journal of Veterinary Research and Animal Science, v. 49, п. 4, p. 318-324, 2012. 
SPINDOLA, B.F.; BOTTEON, P.T.L.; ROCHA, F.F.; CALADO, S.B.; BOTTEON, R.C.C.M.; RODRIGUES, E.M.S.M.; MARINHO, L.M. Brazilian Journal of Veterinary Medicine, v.39, n.3, p.165-169, 2017.

STALEY, M.; CONNERS, M.G.; HALL, K.; MILLER, L.J. Linking stress and immunity: Immunoglobulin $A$ as a non-invasive physiological biomarker in animal welfare studies. Hormones and Behavior, v.102, p.55-68, 2018.

WAGNER, B.; MILLER, D.C.; LEAR, T.L.;ANTCZAK, D.F.The Complete Map of the Heavy Chain Constant Gene Region Reveals Evidence for Seven IgG Isotypes and for IgD in the Horse. The Journal of Immunology, v.173, p.3230-3242, 2004.

WEISS, D. J.; WARDROP, K. J. Schalm's veterinary hematology. 6 th ed. lowa: Blackwell Publishing, 2010.

WULF, M.; BEYTHIEN, E.; ILLE, N.; AURICH, J.; AURICH, C. The stress response of 6-month-old horses to abrupt weaning is influenced by their sex. Journal of Veterinary Behavior, v.23, p.19-24, 2018. 